\title{
The quality of the health care based on bioethics guiding its professional act
}

\author{
Hernández Hernández C. ${ }^{1}$, Tapía Vargas M. ${ }^{1}$, Sosa Sañudo \\ M.P. ${ }^{1}$, Hernández Hernández B.I. ${ }^{1}$, Cortés Ascencio S.Y. ${ }^{2}$, \\ Villa Ramírez G.B. ${ }^{3}$, Aguirre Rembao L.O ${ }^{4}$, Ruvalcaba \\ Ledezma J.C. ${ }^{4^{*}}$
}

${ }^{1}$ Facultad de Ciencias Humanas, Licenciatura en Enfermería Universidad La Salle Pachuca Hidalgo, México.

${ }^{2}$ Profesor investigador [UNADM] Universidad Abierta y a Distancia de México, México.

${ }^{3}$ Licenciatura en Enfermería en [ICSa-UAEH] Instituto de Ciencias de la Salud-Universidad Autónoma del Estado de Hidalgo Pachuca, México.

${ }^{4}$ Departamento de Medicina en [ICSa-UAEH] Instituto de Ciencias de la Salud-Universidad Autónoma del Estado de Hidalgo Pachuca, México.

$5^{*}$ Departamento de Medicina y Salud Pública en [ICSa-UAEH] Instituto de Ciencias de la Salud-Universidad Autónoma del Estado de Hidalgo Pachuca, México.

\section{ARTICLE INFO}

Article No.: 012318009

Article type: Critical Analysis

DOI: 10.15580/GJEPH.2018.2.012318009

Submitted: $23 / 01 / 2018$

Accepted: 26/01/2018

Published: $31 / 03 / 2018$

${ }^{*}$ Corresponding Author

Ruvalcaba Ledezma JC

E-mail:dscpjcarlos@gmail.com

Keywords: health, health care, responsibility, professional bioethics, responsibility.
This is a critical analysis of the quality of health care services depending on the health system fragmentation and the implementation of bioethics by its professional personals acting responsibly in nursing practices. It points out the responsibilities in public health, emphasizing the current health reform that grants professional nursing the ability to take notice of current trends, the ability to prescribe medications in the absence of the physician and the ability to meet the needs of vulnerable patients. This shows that in our country, every day, professional work has increased in health care and should therefore be considered as professional health care, transforming public health situation through bioethics in their professional work denotes greater responsibility. 


\section{INTRODUCTION}

We have observed that in our country, Mexicans right to health care services is fragmented. As we know in the Mexican Constitution in the fourth article, it states that all the population has right to health protection. ${ }^{1}$ As it is mentioned by the author in his article "The Mexican health care system", these days the quality of the attention by health care is notably affected by the quality of the attention given by the different institutions and the economic costs that it represents.

The National System of Information of Health Care mentions the following:

"The Secretary of the Health Care is responsible to promote the establishments of a national system of basic information in health matters." ${ }^{2}$

According to the earlier notions, we can mention that there exists a contradiction since this promotion which it refers to, is not covering all the Mexican population.

The General Law of Health Care in Mexico establishes the functions and the guidelines in order to be able to give the health care services to the population. ${ }^{3}$ But, it seems to be contradictory and unreasonable that the Health Care System in Mexico does not comply with the legal scheme already determined.

Another problem in health matters is the popular insurance because of the geographic position where the units of the medical attention are located, since in the province, for many people it is difficult to reach a health care center where the diagnosis of their disease can be made, including receiving adequate treatment.

The Mexican health care system from its origins has been a system which has always shown data that is alarming and unfortunately real, a system that from its origins has been fragmented and with iniquity in the health care, hence we have to intervene with suggestions to search more viable solutions. ${ }^{3,4}$

Like graduates in nursing, we have to act now and we have to make the changes which Mexico requires in order to get favorable results for everyone. We always should follow the guidelines of the "Code of ethics for nurses in Mexico". It says the following: "the Professional of Health care has a solid formation based on technical-scientific, humanistic and ethical fundamentals which allow them to perform their job with quality and professional awareness." ${ }^{4}$

In respect to the infrastructure of health care for the year 2009, the public sector counts with 1,211 hospitals and 19,534 units of ambulance 0,7 bed/ 1000 habitants, the lowest rate among the countries of the OCDE, Japan 12 and Turkey 2,5/ 1000 habitants respectively. ${ }^{5}$

We have to point out that the Mexican health care system for its integration pretends to have no trace of the iniquity and of the inaccessibility of the health care services, of course it is not a short term goal and we can suppose that a person just because he or she is Mexican could attend and receive medical attention at the closest clinic, independent of which social class he or she comes from. Nowadays the reality respecting the accessibility and the quality of the health care services are uncertain, normally it does not have the basic medications, including the persons who are insured directly just because they are workers and defined as right holders, although it is contributed by a quote depending on the worker's pocket, which is taken away from them via their payroll, they receive medical attention that is limited.

The economically vulnerable persons who are inscribed in a program called "seguro popular", although they have an appointment, have to wait a lot at the doctor's office. It is also limited by the possibility of diluting certain medications for their health problems; this can increase the possibility of not getting the medical treatment or getting a medical attention of a deficient quality. They exaggerate the number of the persons who attend the doctor's office while they give the priority to the insured or the right holders, to the employers and to the federal government. ${ }^{3}$ In the human resources, the health care sector during 2009 had contract with 169.308 doctors $(1,7 / 1000$ habitants), and with 225.144 nurses (2,2/1000 habitants).

The resources for persons without social security has increased, and it is obvious in the health caravans, generally, there exists a variability in the quality of the services, there are units of public and private services with high quality standards, mainly those which are certificated or accredited, although there are some with low concern and safety for patients which facilitate the presence of nosocomial infections between $10 \%$ and $15 \%$ according to the type of the hospital we are studying. This type of infections builds adverse events for the safety of the patient and they require strategic institutional intervention by the Secretary of Health Care. For the year 2008, the Under-Secretary of Integration and Development of the Health Care sector (SIDSS) made a study to measure the prevalence of the adverse events in the surgery services and it was 4,1 in 2008 (128.400), it means that 1 person out of 25 patients who undergo a surgical procedure shows adverse events, these rates indicates the need of establishing mechanisms that permit to minimize this type of medical errors and to increase the quality standards of the attention given by health care. ${ }^{5}$

Another interesting question to talk about is lying in the geographic situation. Like one of the mechanisms as well which intervene in the flow of the resources and in the increase of the demand of the health care services. According to the planned, because of the closeness to the geography, a person or more can look for medical attention in another state and this generates a detour of the economic resources ${ }^{3}$ and therefore it brings like consequence of the reduction in the quality of given attention.

According to the World Health Organization (WHO) the health care systems have 3 goals: 1.- To improve the health state of the population. 2.- To offer a proper treatment for the users of the system. 3.- To avoid that the people make excessive expenses to get the needed health attention. In Mexico, the criterions of 
equity in the giving of attention by health care have a fundamental role. They are considered as well as the goal of the heath care systems, to reduce the inequality in medical attention and to guarantee that the health care contributes to reducing poverty. ${ }^{5}$

To manage to do this, health care needs something what we consider as the mainstay of the health care profession: the bioethics. According to the North American Encyclopedia of Bioethics, it defines bioethics as:

"The study of the human behavior in the field of life sciences and in health care, this behavior is taken to daylight by the moral values and principles." ${ }^{6}$

" El Código de Ética para las enfermeras y enfermeros en México" is based on the principles of bioethics. In this code, they mention that the health care has a commitment to look after and to offer the health care services to all the society. We can observe here something contradictory. As we have mentioned it at the beginning, not the whole Mexican population gets the medical attention and not because there are no institutions of health care. Since there are different institutions of health care, there are those who depend on the worker's quote that works like an "insurance" with which they have access to the health care attention when an illness shows up. Other institutions have a public character, in these, the people pay for the given attention, as much as for the medications and for the days spent in the hospital, these are paid by the persons who needed them.

Every health care institution was created with the intention to develop the quality of the attention and to get a better coverage and access to medical attention. Previously, the access to health care attention was very limited and the people with scarce resources or in poverty did not have insurance or they could not afford the expenses of the medical attention. In the year 2004 the "popular insurance" was created with the faculty to integrate the health care attention and to expand its coverage. They came up with democratization on the first and second level and in the financial protection of the users of the health care services.

\section{How is the financing of the "popular insurance"?}

It works with a tripartite scheme: contributions of the federal government, federative entities and contributions of the members according to their economic situation. The members of the "popular insurance" have to comply with a series of requirements in order to be members of this insurance, for example: regular medical consultations, attending to discussions of first level, to do regularly medical studies, in these activities we can observe that a part of this coverage of this insurance works as prevention, each regular medical consultation helps us to prevent future illnesses which would be more expenses.

The health care institutions are committed to comply with the corresponding health indicators, since the attention should be of high quality and fulfill the goal of the coverage of the health care attention as a right of every citizen. Since a couple of years when the insurance was created, it made sure that a total coverage of the attention and the services is available for the people, it suggested that it would cover the health care services for free and that everyone has the right to purchase a "popular insurance". In 2002, it started as: "Health care program for everyone" (Health program for all) and in 2003 they introduced a law of social protection for the health of the Mexicans.

The popular insurance is defined as: "The popular insurance is a volunteer medical insurance for every Mexican household regardless of the work conditions, the geographical situation, or the capacity of payment without being member of any social insurance institution".

A part of the goals of this insurance says: to decrease the expenses of the health care attention for the people, to reduce the risk of the decrease of the health care attention for economic reasons, to preserve the health to promote the convenient attention to the health care. Today the finances of a Mexican depend on a continuous effort, the health conditions and the benefits of the same conditions are limited. A popular insurance offers a certain coverage but it is conditioned by some aspects which have to be complied; this means that somehow those persons who have this type of insurance are obliged to comply or "to pay" for their right to the insurance with other indications in order to get it. This limits as well the right to the health care owing to the fact that not everybody who has this popular insurance can comply with these indications which leads to the health care coverage been taken from them.

The bioethics indicates to make use of the ethics and the values in order to make good for the other ones, the right to freedom and to act fairly with the others. A paternalistic government can promise to comply with the right to health care but behind this condition to health care there are a series of conditions where the personal values do not matter. If a person has the right to health care the government should respond in a committed way.

Health care involves an expense for the government and the people with scarce resources have looked for this as one possibility of attention. The first level of attention works as prevention and education of the health and now this is looked as one of the determining factors in order for one to have the right to health care.

The public health care institutions as much as the private health care sector counts a progressive increase regarding the quality of attention, it is very important to improve it even though there has been different actions to improve it. In this sector, it is not carried out to perfection which leads to a decrease. As this program of the "popular insurance" has pointed it, there are different institutions for example: National System of Citizen Health Care (NSCHC), the National Committee of Social Protection in Health Care (NCSPHC) that are committed to protect the rights of the recipients of the "popular insurance", because of this it is necessary to have tools to strengthen the mechanisms of participation and the administrative procedures according to the principals of efficiency. With efficiency and transparency, they intend to satisfy 
the expectations of the members and of the citizens in general. $^{7}$

Keeping in mind that the "popular insurance" is a benefit that is given by the Federal Government for those families, which because of their physical, economical or social situation, are not members of any public health care institution for example the IMSS or the ISSSTE and the program wants to strictly involve people who really need this membership in order to improve the health care attention and services.

The rights that the members have are: access to equal medical attention, the user has the right to protect his/her health and to receive the medical attention in the designated establishment within the net of the Health Care of the "popular insurance" without discrimination and waiting, considering a special attention for disabled and elder people. They also have the right to be attended to by a qualified staff at the place where they are being attended to and to be treated with a polite and kind attitude through an understandable language by the medical crew. The members have the right to require privacy and modest respect during the attention. They also have the right to receive the $100 \%$ of the medications prescribed as part of the package.

According to what is said in the article number 64 of the Decree of the Federal Budget for the year 2002, the paper work and the official documentation as the publicity and the and the promotion are as well related to the Health Care Program for Everyone (popular insurance of health) should contain the legend: "This program has a public character it is not supported or encouraged by any political party and its resources come from the money of the taxpayers. It is prohibited to use this program for political intentions or to gain benefits or for other intentions established in it. Who uses the resources of this money in an inappropriate way should be accused and sentenced according to the applicable law in front of the relevant authorities". Any public or personal organization that participates in the operation of the insurance cannot ask for any type of economic cooperation or any political participation from any member or family member of the recipients of the insurance. ${ }^{8,9}$

The introduction of "the popular insurance of health" in April of 2003 approved by the Congress of the Union was surrounded by doubts, speculations and critics and made it evident the need of more information. ${ }^{8,9}$ At the same time the people have access to the information and because of this, the influence of the manipulation of the information is very big and with it the people reclaim their rights as citizens to the health care. In the past, the people did not have open access to the information to reveal doubts about their rights to health care, the doctor was seen as a prominent authority and they did not reclaim the conditions of the health care services. ${ }^{10,11}$

\section{DISCUSSION}

The bioethics as a science of acting has supervised and established ethical norms in the act of the health care workers. Many people have doubted the total coverage of a popular insurance. The access is free but the possibilities to make a high-quality-attention have always been doubtful. Recently, being the president of the Mexican Republic the lawyer and lecturer Felipe Calderón Hinojoza reforms the General Law of Health Care and in the section of the inputs of the health care it states that the professional in infirmary is a professional in health care as well, so he/she can prescribe medication in the absence of the doctor when there is a group of vulnerable people.

This shows that the bachelor's carrier of nursing is increasing; this means that the quality of the professionals and their professional capacity permitted this increase in this field of health sciences. With this fact, the result is an imminent sign that shows that professionals of nursing form part of the health care crew. A person's responsibilities were increased due to his/her humanitarian personality as well. This person will have to work in a team with other professionals in nursing and with other professionals in health care creating multidisciplinary health care teams. ${ }^{11,12}$

To have values-attributes indicated by Fajardo, honesty, knowledge, passion and social sensitivity ${ }^{13,14}$, would avoid corruption, but above all, the human character of the nursing professional accepted and reflected in all the health professionals working as a team, would help to improve the quality of care.

\section{CONCLUSIONS}

To guarantee the quality of the health care services it is necessary that the Mexican health care system has to improve the reform-integration of the health care services.

The nursing professionals have gained ground in increase and recognition at professional level, now they are considered equally as other health care professionals. Beside increasing their responsibilities and modifying the General Law of Health Care, now the nursing profession requires that they learn how to work in team with their pair and with other health care workers forming multidisciplinary teams.

The nursing professional has to compromise from its professional acts in the application of the bioethics at a personal level and at the level of the work too to improve the level of quality of the services from the perspective of working in teams and to recognize and respect the academic curriculum of their co-workers to increase quality of the health care services.

The changes in the General Law of Health Care affect the nursing professionals in two ways. Firstly, they give nurses bigger recognition as executors of the nursing profession. The other way is the increase of the responsibilities in the bioethical act of the nursing professional, but this requires bigger capacity at a professional level. 


\section{ACKNOWLEDGEMENTS}

The authors of the present research article would like to acknowledge and truly thank the collaboration of Lezzly Zaireth Chávez Arizmendi for her contributions on the revision and translation of the article; situation which allows the possibility to increase the transferring and modification of scientific knowledge.

CONFLICT OF INTEREST: The author declares no conflicts of interest.

\section{REFERENCES}

1.-Constitución Política De Los Estados Unidos mexicanos (1917) [en línea] [time of consulting 12/5/2013].

http://www.diputados.gob.mx/LeyesBiblio/pdf/1.p df

2.-Sistema Nacional de Información de Salud (México) [en línea] Marco Jurídico. 12 de Noviembre de 2010. [time of consulting 4/17/ 2013]. Disponible en:

http://www.sinais.salud.gob.mx/acercade/index.h tml

3.- Ruvalcaba Ledezma JC. y Cortés Ascencio SY. El sistema de salud mexicano. ODOUS CIENTIFICA, 2011Vol. 13 № 1,: 34-42

4.- Comisión Permanente de Enfermería CPE (México) [En línea] Código de ética para las enfermeras y enfermeros en México. Diciembre 2001. [Time of consulting:4/22/2013]. Disponible en: www.salud.gob. mx/unidades/cie/cms cpe/

5.-Ortiz Domínguez ME et al. México: Hacia la Integración del Sistema Nacional de Salud Pública, Instituto Politécnico Nacional, Ed. IPN. México. 2010; 9-10

6.-Sistema Nacional de Atención Ciudadana Seguro Popular (México) [en línea] Derechos
Reservados 2010.[time of consulting:4/22/ 2013]. Disponible en: www.seguropopular.salud.gob.mx/index.php?option...id

7.-Seguro Popular de Salud (México) [en línea] Derechos Reservados 2004. [time of consulting: 4/22/ 2013]. Disponible en: www.salud.gob.mx/unidades/dgpfs/faq.htm

8.- Gómez-Dantés O, Sesma S, Becerril VM, Knaul FM, Arreola H, Frenk J. Sistema de salud de México. Salud Publica Mex 2011;53 supl 2:S220-S232.

9.-Gómez Dantés, Octavio and Ortiz, Mauricio Seguro Popular de Salud: siete perspectivas. Salud pública Méx, Dic 2004, vol.46, no.6, p.585-588

10.-Eseverri Chaverri Cecilio, Enfermería facultativa, reflexiones filosófico-éticas, Ediciones Díaz de Santos S.A, 2006: 37.

11.-Avalos García María Isabel, Calidad y gestión de servicios de salud, revista Horizonte Sanitario, Volumen 9, Numero 1, 2010: 9-19 [en línea] [time of consulting: 12/5/2013]

12.-Ley General de Salud. (México) [En Línea]. Insumos para la Salud.Agosto 2013. [time of consulting: 4/25/2013]. Disponible en: http://www.salud.gob.mx/unidades/cdi/nom/com pi/rlgsmis.html

13.- Fajardo, S. Medellín, Del Miedo a La Esperanza (Conferencia en el TEC de Monterrey, México). Recuperado el 07 de septiembre de 2017 desde:

https://www.youtube.com/watch?v=mIKz1GSsXp Q

14.-Hernández Medina M.S, Hernández Serrano C. López González A.L, Barragan López N, Islas Vega I, , Cobián Díaz M. L, Reynoso Vázquez J., and Ruvalcaba Ledezma J. C. Valuesattributes Needed to Make Decisions in Health, from the Essential Functions of Public Health. American Journal of Public Health Research, 2017, 5, (5): 154-158 DOI: 10.12691 / ajphr-5-53. 